\title{
THE INTEGRITY OF EDITORIAL CARTOON DISCOURSE
}

\author{
Widya \\ Department of English Education, Faculty of Language and Art, University of Indraprasta PGRI \\ Jalan Nangka No. 58C Tanjung Barat, Jagakarsa, Jakarta Selatan 12530 \\ widya.center@gmail.com
}

\begin{abstract}
This study aims at analyzing the integrity of editorial cartoon discourse through the devices of cohesion and the patterns of coherence that appear in language and images. The method used in this study is a qualitative method. The results show that the relationship of language and images in the discourse helped to create the topic of each text. The connection between language and images is known from the role of language which gives information on the images, or vice versa, the images clarify things that are expressed through language. The amount of panel-to-panel transition which is higher than the amount of language cohesive devices indicates that in PR buat Presiden, the images play more important role than language in developing the integrity of discourse. The data show that without images, it is often difficult to understand the language.
\end{abstract}

Key words: discourse, editorial cartoon, cohesion, coherence

\begin{abstract}
ABSTRAK
Penelitian ini bertujuan untuk menganalisis kepaduan wacana kartun editorial melalui perantiperanti kohesi dan pola-pola koherensi yang muncul dalam bahasa dan gambar. Metode yang digunakan dalam penelitian ini adalah metode kualitatif. Hasil penelitian menunjukkan bahwa hubungan bahasa dan gambar dalam wacana membantu terbentuknya topik setiap text. Hubungan itu terlihat dari peran bahasa yang memberi informasi tentang gambar, atau sebaliknya, gambar memperjelas hal yang dikemukakan oleh bahasa. Jumlah transisi dari panel ke panel yang lebih tinggi daripada jumlah peranti kohesif bahasa mengindikasikan bahwa dalam "PR buat Presiden" ini peran gambar yang lebih dominan daripada bahasa untuk membentuk keutuhan wacana. Data menunjukkan, seringkali akan sulit untuk memahami bahasa yang digunakan tanpa dibantu oleh gambar.
\end{abstract}

Kata kunci: wacana, kartun editorial, kohesi, koherensi 


\section{INTRODUCTION}

Discourse as a term, implies a complex meaning and sometimes is not easy to explain. Discourse is closely related to the use of language. Discourse is a linguistic element that is relatively complex and complete. It can also be regarded as a text plus context. When someone is trying do analyze a discourse, the first thing to do is paying attention to the text. Nevertheless, sometimes the text will not be fully understood by only paying attention to the text itself. It must also be related to the context, both linguistic and nonlinguistic. Because of that point of view, discourse is a pragmatic language element.

Mulyana (2005:25-26) says "A discourse is required to have structural integrity." The integral discourse must meet some integral aspects such as, cohesion, coherence, topic of discourse, lexical aspects, grammatical aspects, phonological aspects and semantic aspects. The integrity of discourse is also supported by the context of discourse. Comprehensively, it can be said that the unity of discourse can occur on the interconnections between the two main aspects of discourse, that is, text and context.

When reading a text, it is obviously seen that there is linkage among sentences or utterance which makes the text understandable. The linkage is created by utilyzing two concepts, cohesion and coherence. Renkema (2004:103) states "Cohesion refers to the connections which have their manifestation in the discourse itself, while coherence refers to the connections which can be made by the reader or listener based on the knowledge outside the discourse. Halliday and Hasan (1976) argue that cohesion is semantic relationship within a text. Cohesion will appear when the interpretation of an element within a text depends on the other elements in the text or discourse. In other words, an element presupposes other elements. "Coherence, in the concept of discourse, means the linkage of meaning or content of a sentence" (Tarigan, 1987:32). Coherent discourse has the unity of meaning because the message is neatly interwoven and it is easily interpretable.

One type of discourse that can be an object of analysis is editorial cartoon discourse. Editorial cartoon is a type of cartoons that is also well known as political cartoon. Wijana (2003) states that editorial cartoon is as illustrations containing a political or social message that usually relates to current events or personalities. In general, language and images are two means used to convey message in editorial cartoon discourse. The language of editorial cartoon is in the form of utterance, narrative, and interjections, while the editorial cartoon image is in the form of objects, people, word balloons, and symbols. The integrity of editorial cartoon discourse is formed by combination of language and images. This makes editorial cartoon discourse becomes a very interesting object to study. This research is about the connection made by verbal language, in the form of whether narrative or utterance, and non-verbal language, especially in the form of images, which build the integrity of editorial cartoon discourse.

McCloud wrote a book in 1993 entitled Understanding Cartoon: The Invisible Art. In that book McCloud discuss about comic, especially. Nevertheless, what he says about comic can also be applicable to editorial cartoon because basically, editorial cartoon and comic cartoon are two related things. Comic cartoon and editorial cartoon are two types of cartoon besides gag cartoon (Wijana, 2003). 
According to McCloud (1993:9) comics are "Juxtaposed pictorial and other images in deliberate sequence, intended to convey information and / or to produce an aesthetic response in the viewer". A series of images in a comic is a series of comic panels. "Panels hold in their borders to all of icons that add up to the vocabulary of comics" (McCloud, 1993: 98). Icon is an image that represents a person, place, thing, or an idea. The icons in comic can be images (people or objects), symbols which function as the background image, onomatopoeic, or figures of utterance that is written in the word balloon. "Words, images, and other icons are the vocabulary of the language called comic" (McCloud, 1993:47). Editorial cartoon is also presented in the form of panels, usually one panel on a page, which consist of images, symbols, onomatopoeic, and word balloon.

Editorial cartoon context, both linguistic context and nonlinguistic context, is needed to understand the delivered message. Linguistic context by Firth in Keraf (1994:32-33) is "The relationship between a language element to another elements; nonlinguistic context is the relationship between words and things; and the relationship between language and society (social context)." Social context includes three things. First, the relevant traits of participants in the form of verbal action, namely the use of language according to the situation and the non-verbal action which is non-linguistic behavior; second, the relevant objects, the subject that affects language; and the third, the effect of verbal action that affects the choice of words.

Hidayat \& Zaimar quoted in Rinanti (2000) state "Verbal action or verbal language in comic is words which function as the communication tool between the narrator and the reader, either directly or through the communication of the character." Comic artist acts as the narrator when explaining the situation to the reader. Narrative language in general is a standard language. The language used by characters which is usually written in word balloons is in a variety of conversations in informal situations and regional diversity. On the other hand, non-verbal action in comic is expressed through symbolic language. By using simbolic language writer tries to express the comic characters feeling.

Hidayat \& Zaimar in Rinanti (2000) analyzed the communicative aspects of the comic to show that a range of neutral language and regionalism in the utterance, slang, and interjection. In addition, there are onomatopoeic and symbols that make the comic communicative. The data used is fifteen Indonesian comics from different genres such as legend, myth, fable, action, satire, history, and religion. In this study, they did not analyze the relationship between language and image to form the integrity of the comic discourse. Therefore, this present study is aimed at analyzing the integrity between language and images which appear through the elements of cohesion and the patterns of coherence in editorial cartoon PR Buat Presiden written by Benny Rahmadi in 2014. PR buat President is the compilation of editorial cartoons that had been published in weekly and daily KONTAN. Benny Rahmadi is a editorial cartoon artist who has made editorial cartoon for weekly and daily KONTAN continuously since 1998-present. He has written 13 editorial cartoon books which have been already published by Kepustakaan Populer Gramedia since 1997.

One of the previous studies that is closely related to this present study is the one done by Rinanti (2000). Her writing 
is aimed at analyzing the connecting elements in language used in comic cartoon discourse. Besides, it is also aimed at analyzing the connection between language and images in creating the unity of discourse. In her writing, she applies the concept of cohesion suggested by Halliday and Hasan in their book Language, Context, and Text: Aspects of Language in a Social-semiotic Perspective (1992) and is combined with concept suggested by Keraf (1994). Meanwhile, in this present study, the write is applying the concept from Halliday and Hasan (1976) in their book Cohesion in English. The analysis is supported by panel-to-panel transition suggested by McCloud (1993) to see the connection between panels within the editorial cartoon. In analyzing the text's coherence the writer is applying the pattern of coherence suggested by Renkema (2004), while Rinanti applies semantic linkage by Halliday \& Hasan (1992). Rinanti found that narrative determine the main theme. The theme developed in the form of characters utterances. She said that images and language can not be separated in creating the unity of discourse.

Halliday \& Hasan (1992:65) mention, "The unity of meaning which is higher than words and structure is text." Therefore, in this study any combination of language and images in the editorial cartoon is regarded as one text. Text is basically a unit of meaning that cannot be given such restrictions such as sentences, but larger. Because of its nature as a unit of meaning, the text should be viewed from two angles simultaneously, i.e. as a product/result and as a process. "As a product, the text is an output, something that can be recorded and studied because it has a certain arrangement that can be expressed systematically," (Halliday \& Hasan, 1992:13). Text as a product in this study is the output of the panels.

According to McCloud (1993:27), "Panel is the images that store all the iconic images that enrich the meaning of vocabulary in editorial cartoon". The panel can be classified according to the concept suggested by Cecolini \& Nubbin (1992), the first, multiple panels on one page; second, one panel on one page; and third, a panel of two pages. In this present study, there are 170 panels, 161 panels are one panel on one page, and 11 pages containing multiple panels. "As a process, text is the process of selecting the meaning continuously, a change through the network of meaning, with any devices that form an environment for further devices," (Halliday \& Hasan, 1992:13). Text as a process in this study is a device that forms an environment for further devices, namely the discourse of an editorial cartoon.

Integrity of discourse in this study includes verbal and nonverbal discourse integrity. It is assumed that the integrity of editorial cartoon discourse is produced by the connection between these two elements. They support each other and the absence of one of the elements will influence the reader's interpretation toward the discourse. The interpretation of an editorial cartoon can be easier if there is context supporting the verbal and nonverbal elements. Because it is about politics or social problem, the context can be known by reading some related articles talking about the discussed topic.

Halliday \& Hasan (1976) outline taxonomy of types of cohesive relationships which can be formally established within a text and bind a text together. They studied cohesion in English and discovered two categories of cohesive devices: grammatical cohesive devices covering reference, ellipsis, substitution and conjunction, and lexical cohesive devices including reiteration 
and collocation.

According to Halliday \& Hasan (1976) reference, as one type of cohesion, deals with a kind of semantic relation whereby information needed for the interpretation of one item is found elsewhere in a text. Reference is classified into personal reference, demonstrative reference and comparative reference. Another type of grammatical cohesion is substitution and ellipsis. "Ellipsis refers to something left unsaid," (Halliday \& Hasan, 1976:142). There is no implication that what is unsaid is not understood. On the contrary, 'unsaid' implies 'but understood' nevertheless. An elliptical item is one, which leaves specific structural slots to be filled from elsewhere. This is exactly the same as presupposition by substitution, except that in substitution, an explicit 'counter' is used, like one or do, as a place-marker for what is presupposed. But in ellipsis, nothing is inserted into the slot. That is why we say that ellipsis can be regarded as substitution by zero. Like substitution, there are nominal ellipsis, verbal ellipsis and clausal ellipsis. The last one is conjunction. Conjunction is a specification of the way in which what is to follow is systematically connected to what has gone before. It is somewhat different from the other cohesive relations. It can be used to realize the systematic relationship between sentences or paragraphs in a text.

Lexical cohesion refers to the links between the content words which are used in subsequent segments of discourse. Two types of lexical cohesion can be distinguished: reiteration and collocation. According to Halliday \& Hasan (1976:278), "Reiteration is a form of lexical cohesion which involves the repetition of a lexical item, at one end of the scale, the use of a general word to refer back to a lexical item, at the other end of the scale, a number of things between the use of a synonym, nearsynonym, or superordinate." Renkema (2004) adds another lexical relations into reiteration namely antonymy, hyponymy/hyperonymy, and meronymy. All of the lexical relations will be applied in analyzing the data of this present study.

Collocation describes the relationship between words that tend to co-occur. Halliday \& Hasan (1976:287) refer to the term collocation as a "general heading" or a "covering term." Collocation is the most problematic part of lexical cohesion, which is achieved through the association of lexical items that regularly co-occur. In other words, collocation is just a covering term for the cohesion that results from the cooccurrence of lexical items that are in some way or other associated with one another in similar environment. Similar environment here means, that those two or more words that collocate to each other would tend to appear in the same context.

The concepts about image connections through panel-to-panel transition suggested by McCloud (1993:70-72) is used to analyze the integrity of nonverbal discourse found in editorial cartoon. McCloud says that most panel-to-panel transition in comic cartoon can be placed in one of several distinct categories: (1) moment-tomoment which requires very little closure; (2) transition featuring a single subject in distinct action-to-action progression; (3) subject-to-subject while staying within a scene or idea. in this transition, the degree of reader involvement is necessary to render the transition meaningful; (4) scene-toscene transition which transports us across significant distance of time and space; (5) aspect-to-aspect which bypasses time for the most part and sets 
a wandering eye on different aspect of a place, idea, or mood; (6) no-sequitur which offers no logical relationship between panels whatsoever. For this last category, McCloud says that no matter how dissimilar one image may be to another, there is a kind of spontanous or natural linking at work in the space between panels which can help us find meaning or resonance in even the most jarring combinations.

Brown \& Yule (1983:224) insist, "Coherence means unity between units in a text or speech." In the structure of discourse, the aspect of coherence is needed to organize the inner linkage between a proposition to another to obtain the unity. The coherence is elaborated by the meaning relationships between elements semantically. Renkema (2004:108-109) divides some semantic relations between parts into additive relations and causal relations. The additive relations is closely related to conjunction, especially coordinating conjunction, which has been discused in grammatical cohesive devices. Among the coordinating relations those are which can be represented by words such as and (addition), but (contrast), or (disjunction), or an equivalent of these words. A causal relation, on the other hand, can be related to an implication.
The most important causal relations are seven types distinguished in traditional grammar: cause, reason, means, consequence, purpose, condition, and concession.

\section{METHOD}

The method used in this study is descriptive method which explains the relationship between language and image in producing an integral discourse. There are some steps in doing this research namely: (1) classifying the topics of the text. PR buat President is divided into eight topics based on the types of problems that should be overcome by the President; (2) analyzing the cohesion of verbal text and panel-topanel transition; (3) analyzing the coherence of the text, (4) describing the connection between texts to see the integrity of the discourse $P R$ buat Presiden, and (5) drawing the conclusion.

\section{RESULTS AND DISCUSSION}

\section{Cohesion}

The table below shows the amount of cohesive devices found in verbal discourse, either grammatical or lexical cohesions, and the amount of transition from panel-to-panel to produce the cohesion of the text.

Table 1 Cohesive Devices and The Panel-to-Panel Transition in PR Buat Presiden

\begin{tabular}{|c|l|c|c|c|c|c|c|c|c|c|c|}
\hline No & \multicolumn{1}{|c|}{$\begin{array}{c}\text { Cohesive } \\
\text { Devices }\end{array}$} & $\begin{array}{c}\text { Text } \\
1\end{array}$ & $\begin{array}{c}\text { Text } \\
2\end{array}$ & $\begin{array}{c}\text { Text } \\
3\end{array}$ & $\begin{array}{c}\text { Text } \\
4\end{array}$ & $\begin{array}{c}\text { Text } \\
5\end{array}$ & $\begin{array}{c}\text { Text } \\
6\end{array}$ & $\begin{array}{c}\text { Text } \\
7\end{array}$ & $\begin{array}{c}\text { Text } \\
8\end{array}$ & $\begin{array}{c}\text { Text } \\
9\end{array}$ \\
\hline & Language & & & & & & & & & & \\
1. & Repetition & 11 & 1 & 2 & 4 & 2 & 1 & 10 & 0 & 2 & 31 \\
2. & Synonymy & 1 & 0 & 0 & 0 & 0 & 1 & 3 & 0 & 0 & 5 \\
3. & Hyponymy & 1 & 3 & 0 & 2 & 1 & 2 & 8 & 0 & 0 & 17 \\
4. & Meronymy & 8 & 0 & 2 & 0 & 1 & 0 & 6 & 0 & 0 & 17 \\
5. & Antonymy & 4 & 0 & 0 & 0 & 0 & 1 & 3 & 0 & 0 & 7 \\
6. & Collocation & 23 & 3 & 5 & 1 & 0 & 2 & 6 & 1 & 0 & 41 \\
7. & Substitution & 2 & 0 & 0 & 0 & 0 & 0 & 0 & 0 & 0 & 2 \\
8. & Ellipsis & 2 & 0 & 0 & 0 & 0 & 0 & 0 & 0 & 0 & 2 \\
9. & Reference & 2 & 0 & 0 & 0 & 0 & 0 & 0 & 0 & 0 & 2 \\
\hline
\end{tabular}




\begin{tabular}{|c|c|c|c|c|c|c|c|c|c|c|c|}
\hline 10. & $\begin{array}{l}\text { Conjunction } \\
\text { Total }\end{array}$ & 6 & 0 & 0 & 0 & 0 & 0 & 0 & 0 & 0 & $\begin{array}{c}6 \\
130\end{array}$ \\
\hline 1. & $\begin{array}{l}\text { Images } \\
\text { Moment to } \\
\text { moment }\end{array}$ & 0 & 0 & 0 & 0 & 0 & 0 & 0 & 0 & 0 & 0 \\
\hline 2. & Action to action & 7 & 0 & 0 & 1 & 0 & 4 & 1 & 0 & 0 & 13 \\
\hline 3. & $\begin{array}{l}\text { Subject to } \\
\text { subject }\end{array}$ & 4 & 2 & 3 & 3 & 0 & 7 & 1 & 1 & 1 & 22 \\
\hline 4. & Scene to scene & 5 & 4 & 1 & 2 & 1 & 7 & 1 & 1 & 0 & 22 \\
\hline 5. & Aspect to aspect & 2 & 0 & 4 & 3 & 0 & 11 & 3 & 0 & 0 & 23 \\
\hline 6. & $\begin{array}{l}\text { No sequitur } \\
\text { Total }\end{array}$ & 15 & 5 & 3 & 0 & 3 & 29 & 2 & 9 & 2 & $\begin{array}{r}68 \\
148\end{array}$ \\
\hline
\end{tabular}

From the table above, it can be seen that cohesion of each text is achieved through the cohesive devices, either language or images. The language can be in the form of narrative or utterance. In PR buat President utterances is much more than narrative. The utterances can be in the form of monolog or dialogue. Meanwhile, the editorial cartoon images are in the form of objects, people, word balloons, and symbols. The amount of panel-to-panel transition which is higher than the amount of cohesive devices indicates that the images play more important role than language in developing the cohesion of the text in this editorial cartoon book. The data show that without images, it is sometimes difficult to understand the language. The images clarify things that are expressed through language.

If compared to grammatical cohesion, lexical cohesions are used more frequently. The most frequent one is collocation. The amount of the use of lexical cohesion shows that the cohesion of each text is constructed by the word choices that have the meaning connection to each other. Collocation is the most frequent lexical cohesion apprearing in the discourse because it is the relationship between words on the basis of the fact that these often co-occur in the same surrounding. Conversely, the use of grammatical cohesion that is much less than lexical ones shows that in each text, the editorial cartoon artist creates sentences or sentence fragments which are separated from each other or they are not bound grammatically. However, despite that fact, text cohesion is still achieved because of the role of images and context, knowledge outside language. The context of the text can be seen from newspapers' articles related to the topic of each texts. For example, an article of Tempo.co on Thursday, October 30, 2013 entitled "Cabut Pentil Diakui tak Punya Dasar Hukum" which can help the interpretation of panel 76 of text 5 (confusing government policies) or the article entitled "Demokrat sebut KPK Tebang Pilih Tangani kasus Korupsi" (Merdeka.com, December 20, 2012) which is related to topic of panel 49 in text 3 (the problem of corruption).

Non-verbal discourse cohesion, in this case, the images, can be seen from the connection between panels. The most frequently occur panel-to-panel transition is no sequitur transition. This is because the way the editorial cartoon artist presents the story is by jumping from one idea to another idea but still remains in the same topic. For example, 
in text 6 (panel 77-149) which talks about the economic problem, the story jumps from one idea, the raising of fuel price, to another idea, the labor. The labor problem jumps to another problem, that is, the rising prices of basic commodities, and so forth. Although they seem to show no logical relationship, actually, there is a bond among them that is, communicating the same topic.

\section{Coherence}

Coherence in discourse can occur because of the connection between parts semantically. The interrelated parts will constitute the full and complete meaning (coherent). Coherence causes those parts of discourse form a unity of meaning comprehensively. In creating discourse integrity, the pattern of coherence is supported by context. Coherence means the connection which can be made by the readers or the listeners based on the knowledge outside the discourse. That is why, the interpretation will be better if the readers relate what they read in the text and what they see through images with previous knowledge they have. In order to do such thing, this discourse is divided into several topics.

Topic that binds a panel to other panels in the text 1 is a presidential campaign period. This is where the coherence of the text is visible. The entire panels although are not in chronological order, are under the same topic. Panel 1 as the opening panel, introduces readers to the main topic of the discourse, the number of president's responsibility. Panel 2 is the opening panel for text 1 that introduces reader to the text content. The word "hingar bingar" and the hand movement of the subject leads us to the subject of the next panel, panel 3, which is the gateway for readers to enter into the text 1 , the presidential campaign which is collocated to the word "hingar bingar". The content panels, the panel 3 to panel 34, tells what happened during the presidential campaign. Text 1 is ended by a closing panel, panel 34, which shows an image of a candidate who fails at the election. It is also the end of the election. Panel 35 is a transition panel from text 1 to text 2 .

Topics of text 2-8 respectively are as follows: the bad habit of state officials (text 2, panel 35-46), the problem of corruption (text 3, panel 47-59), infrastructure issues (text 4, panel 60$70)$, the confusing government policies (text 5, panel 71-76), economic problem (text 6, panel 77-149), the problem of natural disasters (text 7, panel 144-153), and problems of gangster and crime (text 8, panel 153-167). Each panel is developed as what has been explained about text 1. Text is opened and introduced by the opening panel which leads the reader to the content panels and it will be ended by a closing panel.

Besides the topic of each text that relate to each other in creating coherence of the discourse, many sentences in editorial cartoon PR buat President also have an important roles by showing symptoms of coherence. Some patterns of coherence contained in this editorial cartoon can be described as follows:

a. Cause

A cause indicates a consequence that is outside the domain of volition.

1) A: "Rasanya tempat kita jauh dari laut, deh. Lalu ngapain lu bikin beginian?

B: "Musim hujan, musim banjir!!" bakal banyak laut di sekitar kita. Gue mau bisnis transportasi alternatif."

Beginian in A refers to a boat made by B. A is curious because they do not live near the sea but his friend (B) is making a boat. 


\section{b. Reason}

A reason always indicates that a volitional aspect is present.

2) A: "Infrastruktur rusak bukan karena cuaca ekstrem. Dari awal bikinnya asal jadi dan ngga dipelihara!" B: "Atau... anggarannya dikorup?"

3) A: "Masak resep baru? Ikannya dijemur dulu?"

B: "Bukan!!" Gas 3 kg langka, jadi nyoba masak pake tenaga matahari. Kali aja Bisa mateng."

4) A: "Kalau kita ngga dapat kursi lagi, DPR bakal sepi...Jadi ngga seru, serba serius."

B: "Mungkin karena lawakan kita selama ini ngga lucu."

5) A: "Lho... kok putar balik? Bukannya kita mesti lewat situ?" B: "Serem, ah! Takut lewat jembatan buatan pemerintah!"

The text in example (2) occurs on the road while two men are in their car talking about the damaged road. The road is perforated. The holes resulted in a muddy road. The example (3) occurs when a man seeing a old woman is cooking under the sun. He is asking that sentence because he does not see any gas used to cook. The example (4) is between two characters wearing clown costume walking outside the parliament building. From the image and the language used it can be seen that those two characters are ex-board members who have been regarded as 'clown' in the parliament. Text (5) is between a couple riding a motor cycle who have to turn around because the man is afraid of the bridge built by government.

c. Means

A means is a deliberate utilization of a cause in order to achieve a volitional consequence.

6) A: "Jangan hujan!"

B: "Jangan hujan!"

C: "Jangan hujan!"

All of the participants in this text are saying the same utterance while doing ritual things to prevent the rain. The first one is burning incense, the second one is throwing underpants, and the last one is lifting a pair of union and chilly into the sky. Those three things are means utilized to prevent the rain. In this text coherence occurs by connecting language and image.

d. Consequence

A concequence is a result or effect, typically one that is unwelcome or unpleasant.

7) A: "Yang bener aja, Bang! Ini bakso apa kelereng? Kok, sekarang jadi kecil amat?

B: "he..he..he.. Map, Neng! Dagingnya lagi mahal dan langka."

This example is a dialog between a customer and a meatball seller. The customer is surprised because of the small size of meatball.

e. Purpose

A purpose is a volitional consequence.

8) A: "Bukannya kalau puasa makan kita jadi berkurang?Kok, belanja makanan seabrek?"

B: "Ya...untuk balas dendam waktu buka."

Example (8) is a dialog between husband and his wife who has just shopped a lot of groceries. 
f. Condition

A condition is a necessary or possible cause or reason for a possible consequence.

9) A: "Apa boleh buat. Rumah dan mobil aku gadaikan buat" biaya kampanye, Bu!"

B: "Kalo gagal jadi anggota dewan, kita jadi gembel, Pak!"

10) A: "Perbaikan jalan rusak nungguin musim kemarau?"

B: "Jangan-jangan nunggu sampai ganti presiden!"

Dialog (9) is between husband and wife who are standing infront of their house. The husband is nervously holding a bundle of money. There is also a man holding a certificate and BPKB. It seems that the husband has already pawn his house and car for the election campaigns. Dialog (10) is between two men on their motorcycle talking about the damaged road. The road is perforated. The holes resulted in a muddy road.

\section{g. Concession}

A concession is a cause or reason for which the expected consequence fails to occur, or the yielding of a point.

11) A: "Indahnya koalisi...bagaikan langit membiru dan padi menguning."

B: "Tapi pangan tak terjangkau, sekolahku ambruk dan lumpur tetap menyembur."

The example (11) shows a different condition between the member of politic parties and a boy living in a rural area. There is no the image of member of politic parties but the word balloon pointing to an object outside the panel and the word 'koalisi' can be considered as the hint of character saying sentence inside the word balloon. The purpose of using the patterns of coherence is to create a discourse structure that is proportional, coherent and logical. Proportional means suitable, fit, and harmonious. Proportionality lies in the connection between language and images in editorial cartoon discourse. Coherent means systematic and interlocked with each other. Logical means sensible, fair, clear, and easy to understand.

\section{CONCLUSION}

Discourse can also be realized with a blend of language and images. Editorial cartoon is one of discourse types which utilizes language and images to produce integral meaning. The relationship between language elements, both narrative and utterance, and the images, supports he creation of topic of each text. Based on the topics that appear in any of the text, it can be seen a description of the problems that must be faced by anyone who becomes the President of Indonesia. The connection among the topics create an overarching topic of the discourse. Then, the relations between language and images are known from the role of language which gives information on the image, or vice versa, images clarify things that are expressed through language. Images cannot be separated from the narrative or the utterances because the images tend to be not sequential in conveying message, as well as the language, especially in this editorial cartoon, which badly needed images and context to be interpreted properly. The amount of panel-to-panel transition which is higher than the amount of language cohesive devices indicates that in PR buat Presiden the images play more important role than language in developing the integrity of discourse. The data show that without images, it is often difficult to understand the language. 


\section{REFERENCES}

Brown \& Yule. (1983). Discourse Analysis. Cambridge: Cambride University Press

Cecolini, V \& Nubbin, J. (1992). Editorial Cartoon: The beginning Collector. New York: The Mallard Press.

Halliday, M.A.K \& Hasan, R. (1976). Cohesion in English. London: Longman

(1992). Language, Context, and Text: Aspects of Language in a Social-semiotic Perspective. Oxford University Press: London.

Hidayat, R.S. \& Zaimar, O.K.S. (1998). "Aspek komunikatif dalam Komik Indonesia". Seminar Komik Nasional. Jakarta.
Keraf. G. (1994). Komposisi: Sebuah Pengantar Kemahiran Bahasa. Ende: Nusa Indah.

McCloud, S. (1993). Understanding Comic: The Invisible Art. New York: Kitchen Sink Press.

Mulyana. (2005). Kajian Wacana. Yogyakarta: Tiara Wacana.

Rahmadi, B. (2014). PR buat Presiden. Jakarta: Kepustakaan Populer Gramedia.

Renkema, J. (2004). Introduction to Discourse Study. Amsterdam: John Benjamin.

Rinanti, C. (2000). Keutuhan Wacana Komik (Skripsi). Universitas Indonesia.

Tarigan, H.G. (1987). Pengajaran Wacana. Bandung: Angkasa

Wijana, I.D.P. (2003). Kartun: Studi Tentang Permainan Bahasa. Yogyakarta: Ombak 